\title{
Dog-Man Isomorphism: Gaze Companion Species with Empathy in Disgrace
}

\author{
Yongjin $\mathbf{W u}^{*}$ \\ Hunan Normal University, Hunan Changsha 410081, China.
}

\begin{abstract}
Based on the self-built corpus, Disgrace is compared with Coetzee's other 11 novels with AntConc to generate keyword list and the data reveals that "dogs", as an important keyword, makes a great contribution to theme construction of Disgrace and has a relationship of co-occurrence and isomorphism with man. Dogs are the objects of Lurie's gaze, and with anti-gaze ,he achieves empathy between man and dogs, clarifies the identity of dogs as companion species of human beings, showing th e isomorphism between them. Lurie's becoming dog-man, which is, in essence, a kind of deterritorialization, breaking through th e species boundary between humans and animals and demonstrates the animal rights.
\end{abstract}

Keywords: Coetzee; Disgrace; corpus; AntConc; Dog-man; Isomorphism

\section{Introduction}

In Coetzee's novels, animal images always appear and reveal his defence of the rights of animals. The prominent animal image in Disgrace is "dogs". In the background of post-apartheid, dogs in South Africa accidentally become the objects of Lurie's gaze. In contrast to Lurie's poetic view of animals, which he inherited from European romanticism, these dogs, with their complex historical and political discourse, are as homogenous and impure as human beings ${ }^{[1]}$.

\section{Corpus-based study on Disgrace with Coetzee's other 11 novels as a reference corpus}

Coetzee's other 11 novels-In the heart of the country(1976), Waiting for the Barbarians(1980), Life and Times of Michael K(1983), Age of Iron(1990), The Master of Petersburg(1994), Lives of Animals(1997), Elizabeth Costello(2003), Slow Man(2005), Diary of a Bad Year(2007), The Schooldays of Jesus(2013), The Childhood of Jesus(2016) - compose a reference corpus, which is 5 times larger than the corpus of Disgrace, and the noun list of Disgrace's keywords - theme words, is generated by AntConc, as follows:

From the above table, it is found that Disgrace is a novel about Lurie, Lucy, Petrus, Bev, Melanie, Soraya, Byron, Wordsworth, Teresa, dogs and goat(perhaps a symbol of scapegoat); a story about white and black(Melanie, which means "black" in Greek), man and woman, father and daughter, professor and student, man(Human) and dog(Animal), opera/desiree(literature) and farm/ stall(reality). Simply put, Disgrace is composed of sex, gender, race, species and lineage. And through the whole list, dogs (include Katy, bulldog, and bitch) totally have connection with all the other theme words, which, to some extent, can be demonstrated by the "dogs" in Concordance Plot by AntConc, as follows:

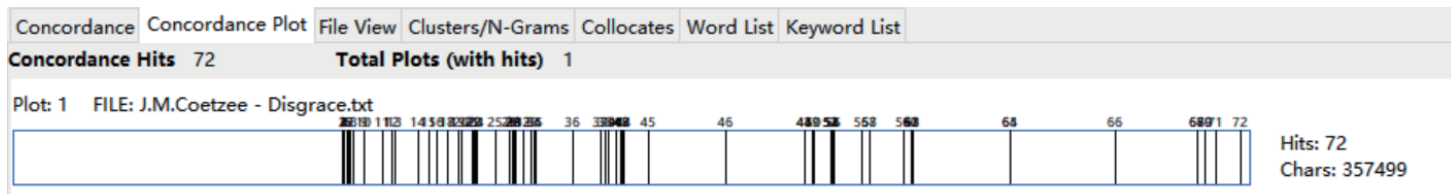

From the above diagram, "dogs" appears in Chapter8-24(except Chapter17, 19, 21), totally in 15 chapters and 72 times, which reveals that "dogs" runs through the full text; that is, "dogs" are actually involved in almost all of main plots, and belong to one of pillars of theme. Meanwhile, the frequent co-occurrence of man and dog illuminates the isomorphism of man and dog.

Copyright (C) 2020 Yongjin Wu

doi: 10.18282/1-e.v9i4.1684

This is an open-access article distributed under the terms of the Creative Commons Attribution Non-Commercial License (http://creativecommons.org/licenses/by-nc/4.0/), which permits unrestricted non-commercial use, distribution, and reproduction in any medium, provided the original work is properly cited. 


\begin{tabular}{|c|c|c|c|c|c|c|c|}
\hline Rank & Freq & Keyness & Keyword & Rank & Freq & Keyness & Keyword \\
\hline 1 & 358 & 1736.72 & Lucy & 29 & 14 & 67.85 & Katy \\
\hline 2 & 258 & 1251.25 & Petrus & 30 & 31 & 66.59 & Cape \\
\hline 3 & 95 & 460.52 & Bev & 31 & 19 & 65.64 & committee \\
\hline 4 & 85 & 412.03 & Shaw & 33 & 13 & 63 & Grahamstown \\
\hline 5 & 73 & 353.85 & Melanie & 34 & 12 & 58.16 & Helen \\
\hline 7 & 71 & 344.16 & Byron & 35 & 12 & 58.16 & Kombi \\
\hline 8 & 70 & 339.31 & Isaacs & 36 & 12 & 58.16 & Rassool \\
\hline 9 & 61 & 295.68 & Lurie & 37 & 10 & 48.46 & banjo \\
\hline 10 & 46 & 195.82 & Teresa & 38 & 10 & 48.46 & Pollux \\
\hline 12 & 71 & 147.16 & dogs & 39 & 54 & 46.95 & car \\
\hline 13 & 49 & 145.52 & professor & 40 & 72 & 45.65 & house \\
\hline 14 & 30 & 145.4 & Soraya & 41 & 9 & 43.62 & bulldog \\
\hline 16 & 61 & 115.74 & daughter & 42 & 9 & 43.62 & rector \\
\hline 17 & 23 & 111.47 & Ettinger & 43 & 21 & 41.98 & student \\
\hline 18 & 23 & 111.47 & Rosalind & 44 & 8 & 38.77 & Farodia \\
\hline 19 & 82 & 99.74 & David & 46 & 17 & 36.12 & pipe \\
\hline 21 & 24 & 98.04 & Bill & 49 & 14 & 35.6 & rape \\
\hline 23 & 17 & 82.39 & Wordsworth & 50 & 12 & 34.45 & bitch \\
\hline 24 & 16 & 77.54 & Mathabane & 51 & 7 & 33.92 & incinerator \\
\hline 25 & 15 & 72.7 & Hakim & 53 & 15 & 33.89 & goat \\
\hline 27 & 22 & 68.73 & clinic & 54 & 9 & 33.56 & counselling \\
\hline 28 & 14 & 67.85 & Desiree & 55 & 9 & 33.56 & opera \\
\hline
\end{tabular}

\section{Isomorphism between man and dog}

\subsection{The white dog}

The white dog can be seen as the representative of the white. White police used white dogs as police dogs to suppress black rebellion during the national movement of South Africa in the 20th century. They became war machine of white's government and during the apartheid era, and in ordinary white families, dogs are "bred to snarl at the mere smell of a black man"[2] (Coetzee, 2000:110). Thus, "[d]ogs are cooped in cages seems to suggest that in post-apartheid South Africa it is inevitable that the white

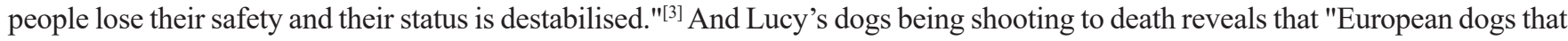
Lucy formerly consider powerful and available to defend her are now entirely powerless and impotent "[3].

\subsection{The black dog}

The black dog is a nickname for the black. In Disgrace, the black who raped Lucy are portrayed "like dogs in a pack."(159) When Lucy recognizes the young man who assaults her, the boy is once more depicted as a "running dog" (131). Rather, Lurie regards the boy who raped Lucy as a "jackal boy" (202). Petrus has his description that " 'The dog-man,' he repeats, savouring the phrase" (64). Under the zoomorphic gaze of the white rulers, black South Africans also began to take dogs as objects of hatred, which is because of the history of the European dog as a legal tool of violence to insult and harm the lives of black people, and also because of the hybrid dog such as the African domestic dog being personified as a black symbol full of animality in the white discourse"[1].

\subsection{Isomorphism of man and dog}

In Disgrace, the similarity of man and "dog" can be traced by sex, discord, destiny and it leads to man becoming "dog" and the blurring of racial territory between humans and dogs.

3.3.1 Lurie's gaze at the male dog-Sex

In Lurie's first argument with Lucy, in effort to express his proposition of morality of sex, he mentions that "when you were small, when we were still living in Kenilworth, the people next door had a dog, a golden retrieve."(89) and insists that "no animal will accept the justice of being punished for following its instincts."(90), claiming that "but at the deepest level I think it might have preferred being shot. It might have preferred that to the options it was offered: on the one hand, to deny its nature."(90) From Lurie's point of view, man has the animality and also is driven by sex like dogs, which reveals one aspect of isomorphism of man and dog.

3.3.2 Lurie's gaze at the bulldog—Discard

With the dismantling of apartheid in 1994, the white dog, once an instrument of legal violence, suddenly fell out of favor, becoming a political pariah that witnessed South Africa's upheavals. Similarly, Lurie lost his job as a professor in the university due to his sex scandal with his student. Abandoned by society, he ended up, with his history of evasions, in the countryside. From this aspect, Lurie and the dog were both marginalized with Lurie being racial other and Katy being animal other. The marginalized need spiritual comfort and desire for love and respect; and the experience of being marginalized also tends to make man better able 
to understand the situation of the other marginalized and show them the ability to love them. It was through the dog that Lurie, who suffered from multiple oppressions, that found spiritual comfort and filled his empty soul. Lurie desires him being understood, and has the need for love and dignity. Katy, who is in the same marginalized position as this abandoned man, makes him seem to see another self, which reflects the isomorphism of man and dog, from which the empathy between man and dog is stimulated, and so that Lurie became close to Katy in the end.

3.3.3 Lurie's gaze at the dog, Driepoot-Destiny

By observing animals and naming them, man gains the status of subject for themselves. However, because of animals' inability to express themselves in language, they can neither observe humans nor name humans. Lurie developed a strong attachment for Driepoot, but in spite of this, he tried not to give this dog a name. The nature of human gaze at animals is to completely ignore animal nature, give animals their requirement according to human standards, and control animals with human will. However, it is under the animal gaze that Lurie attained emotional bond with dogs, gradually lost his human-centered superiority, and finally became a dog-man in the process gaze and anti-gaze. "He can save the young dog, if he wishes, for another week. But a time must come, it cannot be evaded, when he will have to bring him to Bev Shaw in her operating room" (219). Animals cannot decide their own fate and it is the same with man. Lurie was abandoned by the society and nearly died for the revenge of the three black boys. Under such circumstances, Lurie could not control his own destiny. Both dogs and man were fragile and vulnerable to loss with loaded with Disgrace, and the fate of man and dogs likewise points to death, which is not possible to evade.

\title{
3.4 Dogs as companion species of human beings
}

Animals are the companion species of human beings. Animal and human have similar structures on the genetic and physical levels, both of which are derived from the creation of nature. The relationship between humans and dogs is a typical example of the companion nature of species. According to the archaeological research, human and dog enter civilization almost at the same time. Humans completed the domestication of dogs 14,000 years ago, making them companions in grazing, hunting and sentries. It is even possible to say that there is neither a history of people who have been separated from dogs nor a history of dogs who have been separated from humans, and that the two are interdependent on each other along the path of coevolution ${ }^{[1]}$.

\section{Conclusion}

In Disgrace, dog is a prism through which race, species and lineage are illuminated. From the perspective of animals, Coetzee provides a literary appeal to the crisis of violence in South Africa and around the world, urging us to respond to the gaze of animals with an empathic imagination, to accept the ethical responsibility of our companion species in each other's great otherness, and not to make any living creature superfluous in the world. People should harmonize in nature, eliminate the antagonism, cross the boundary of nation state and race, establish a third space full of multi-meanings, and jointly seek for development.

\section{References}

[1]Dan Hansong. Encountering Dogs: On South African Animal Narrative in Coetzee's Disgrace. Foreign Literature Review 2018; (03):166-193

[2]Coetzee, J. M. 2000. Disgrace. New York: Penguin Books

[3]Jiang Lifu. The Politics of the Animal: A Cultural Critique of the Postcolonial Animal Representation in Novels from The White Bone to The White Tiger. 2010. Nanjing University, PhD dissertation.

\author{
About the Author \\ About the author: Yongjin $\mathrm{Wu}(2000.07-$ ), male, born in Yongzhou, Hunan Province. He is an undergraduate at Hunan Normal \\ University. His research interest is British and American literature.
}

\section{Fund topics}

This paper is funded by Hunan Normal University undergraduates innovative experiment project and entrepreneurship program(2020121). 